ECONOMIC CHANGE IN EAST MALAYSIA 
General Editors: Peter Nolan, Sinyi Professor of Chinese Management, Judge Institute of Management Studies, University of Cambridge, and Fellow of Jesus College, Cambridge, England; and Malcolm Falkus, Professor of Economic History, University of New England, Armidale, NSW, Australia

In the last decades of the twentieth century the small and medium-sized nations of East and South-East Asia have begun a process of potentially enormous political and economic transformation. Explosive growth has occurred already in many parts of the region and the more slowly growing countries are attempting to emulate this vanguard group. The impact of the region upon the world economy has increased rapidly and is likely to continue to do so in the future.

In order to understand better economic developments within this vast and diverse region, this series publishes books on both contemporary and historical issues. It includes works both by Western scholars and by economists from countries within the region. 


\section{Economic Change in East Malaysia}

\section{Sabah and Sarawak since 1850}

Amarjit Kaur

Associate Professor and Head

Department of Economic History

University of New England

Armidale, New South Wales

Australia

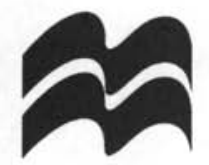


First published in Great Britain 1998 by

MACMILLAN PRESS LTD

Houndmills, Basingstoke. Hampshire RG21 6XS and London

Companies and representatives throughout the world

A catalogue record for this book is available from the British Library.

ISBN 978-1-349-39155-4 ISBN 978-0-230-37709-7 (eBook)

DOI $10.1057 / 9780230377097$

First published in the United States of America 1998 by

ST. MARTIN'S PRESS, INC.,

Scholarly and Reference Division.

175 Fifth Avenue, New York. N.Y. 10010

Library of Congress Cataloging-in-Publication Data

Kaur. Amarjit.

Economic change in East Malaysia : Sabah and Sarawak since 1850 /

Amarjit Kaur.

p. $\mathrm{cm}$. - (Studies in the economies of East and South-East

Asia)

Includes bibliographical references and index.

1. Sabah--Economic conditions. 2. Sarawak-Economic conditions.

I. Title. II. Series.

HC445.5.Z7S2247 1997

$330.9595^{\prime} 3-\mathrm{dc} 21$

$97-34872$

C.IP

(C) Amarjit Kaur 1998

Softcover reprint of the hardcover 1st edition 1998 978-0-333-59713-2

All rights reserved. No reproduction, copy or transmission of this publication may be made without written permission.

No paragraph of this publication may be reproduced. copied or transmitted save with written permission or in accordance with the provisions of the Copyright, Designs and Patents Act 1988, or under the terms of any licence permitting limited copying issued by the Copyright Licensing Agency, 90 Tottenham Court Road, London W1P 9HE.

Any person who does any unauthorised act in relation to this publication may be liable to criminal prosecution and civil claims for damages.

The author has asserted her right to be identified as the author of this work in accordance with the Copyright, Designs and Patents Act 1988.

This book is printed on paper suitable for recycling and made from fully managed and sustained forest sources.

$\begin{array}{llllllllll}10 & 9 & 8 & 7 & 6 & 5 & 4 & 3 & 2 & 1\end{array}$

$\begin{array}{llllllllll}07 & 06 & 05 & 04 & 03 & 02 & 01 & 00 & 99 & 98\end{array}$ 
For

Jan, Noreen Amrita and David Amar 



\section{Contents}

Preface ix

Acknowledgments $\quad$ xi

Preliminary Note xiii

Maps and Figures xiv

Tables $\mathrm{xv}$

Introduction xviii

Part I Themes and Beginnings (c.1850-1940) 1

1 The Historical Setting 3

Administration and Government 9

2 Patterns of Settlement and Production 13

The Demographic Background 15

3 Formation of an Export Economy 20

Mineral Resource Utilisation $\quad 20$

Agricultural Development $\quad 30$

Forests and Forest Resource Utilisation $\quad 56$

Commerce and the State $\quad 68$

4 Economic Frameworks, Policies and the State $\quad 75$

Transport Development $\quad 75$

The Organisation of Labour 93

Economic and Social Transformation 111

Part II The Colonial State, Development Planning and Economic Change, 1946-63 115

5 Britain, Sabah and Sarawak, 1946-63 117

$\begin{array}{ll}\text { The Japanese Interregnum, and the Cession of } & \\ \text { Sarawak and Sabah to Britain } & 117\end{array}$

Reconstruction and Development $\quad 118$

Administrative Reforms $\quad 119$

Economic Reforms $\quad 121$

Mineral Resource Exploitation $\quad 125$

Agricultural Resource Expansion $\quad 131$

Forests and Forest Resource Utilisation $\quad 140$

Transport Development 149

The Organisation of Labour $\quad 159$

$\begin{array}{ll}\text { Foundations for Federation } & 166\end{array}$ 
Part III Sabah and Sarawak in Malaysia: Continuity, Change and Development since $1963 \quad 167$

6 Independence and Federation 169 $\begin{array}{ll}\text { Politics and the Economy } & 170\end{array}$

7 Managing Development 177

The State, Development Planning and Ideology 177

Minerals and Mineral Fuels $\quad 180$

Agriculture and Land Settlement Schemes $\quad 183$

Forests and Forest Resources $\quad 188$

$\begin{array}{ll}\text { Transport } & 198\end{array}$

Whither Change and Development? 201

Appendices $\quad 207$

1 Sarawak: Forest Policy and Legislation 207

2 Sabah: Forest Policy and Legislation 214

3 Sabah and Sarawak: Special Guarantees 215

4 Sabah: Key Political Figures and Parties,

5 Sarawak: Key Political Figures and Parties, 1963-1990 226

$\begin{array}{ll}\text { Notes } & 230\end{array}$

Bibliography 260

Glossary $\quad 284$

Index 286 


\section{Preface}

Sarawak and British North Borneo. The very words have conjured images of headhunters prowling along jungle paths looking for their next victims or white rajahs lording it over the natives and bringing civilisation to them. These two states were faraway lands on the island of Borneo, which was itself off the beaten track. But once in a while, travellers' tales excited western imagination about the fabulous wealth to be had there. It was only in the nineteenth century that a new breed of adventurers set sail for these places lured by their forest products, their promise as new markets and out of scientific curiosity. James Brooke was the most successful of these adventurers and his story has been well recounted by historians and novelists. Others were not so successful. However, since the 1960s the Dipterocarp forests of Borneo have become one of the principal sources of tropical hardwood timber entering world trade. As a consequence of economic change and the transformation of the rainforest environment these remote outposts have suddenly been thrust into the limelight as conflicts arose between different land use, interest and ethnic groups for allocation of land and rights to utilise resources. This has generated debate among scholars, international conservation and environmental organisations and local pressure groups about the nature of and consequences of development, not only for Sabah and Sarawak, but for the Southeast Asian region generally.

My first reason for writing this book is to examine and compare the pace of economic and social change in Sabah and Sarawak, taking a longterm view of their economic growth. The book concentrates on economic development and the role of the state during the first four decades of the twentieth century, but also links the pre- and post- World War II periods. The book's major focus on economic change fills a gap as relatively little has been written on economic development, although a substantial literature exists on the administration of the white rajahs or the British North Borneo Chartered Company. In addition, there are several anthropological and ethnological works on the indigenous groups of the island and their individual economies, and on the Chinese in these states. This book therefore attempts to make Sabah and Sarawak's post-1969 economic development more explicable by considering it in the light of previous growth during the pre 1940 and the 1946-1963/9 periods.

My second reason for writing this book is my interest in the environmental impact of the timber trade, land development schemes and dam construction, all issues of current topicality.

I initially started out with transport and economic change in these states but was persuaded by Malcolm Falkus, one of the editors of the series under which this book appears, to write a book on general economic development. Consequently some of the material on the current 
economic structure is derivative. It was also difficult to decide what to include and what to leave out. There are large gaps in our knowledge of economic development in Sabah and Sarawak, but on some topics and issues, there is an abundance of material. This book has been very much guided by my own interests and knowledge and reflects the availability of sources. Indeed, some readers may feel that a detailed history of every sector has not been provided. It is hoped that omission has not led to misinterpretation. My study is written in the hope that it will stimulate further research on the subject. 


\section{Acknowledgments}

A number of people and institutions made this work possible. The Toyota Foundation funded my initial research work in Sabah, Sarawak and the United Kingdom for the period 1989-1990, while I was employed at the University of Malaya. Subsequent research was funded by a grant from the Australian Research Council and internal research grants awarded by the Faculty of Economics, Business and Law, University of New England, which I joined in late 1990 .

I am most grateful to the following institutions for archival access: Arkib Negara Malaysia; Arkib Negeri Sabah; Sarawak Museum; University of Malaya Library; Institute of Development Studies, Sabah; Public Records Office (London); Institute of Commonwealth Studies (London); School of Oriental and African Studies Library; Rhodes House Library (Oxford); Cambridge University Library; United Nations Library; National Library of Australia; and Dixson Library, University of New England.

I would like especially to record my grateful thanks to Malcolm Falkus for his support and helpful comments.

I would also like to thank my former colleagues at the University of Malaya, especially Khoo Kay Kim, Ranjit Singh and Abdullah Azmi Khalid; in Sabah, James Ongkili, Maximus Ongkili (formerly Director, Institute of Development Studies), and Agatha Matayun (formerly archivist at Arkib Negeri Sabah); and in Sarawak, Hew Cheng Sim, Peter Kedit and Loh Chee Yin (Sarawak Museum). I have also benefited from comments from friends and colleagues working on aspects of Borneo history, especially Robert Cramb, Vincent Houben and Nicholas Tarling. John Drabble was an important source of information and he also gave me helpful comments. My thanks also go to Madeline Entaban Stauffer and Peter Stauffer, and former colonial officials who served in Sabah and Sarawak, especially Neville Haile and Bill Roberts for providing me with colourful insights into the period. To the many colleagues, like Tony Reid, Peter Carey, Colin Barlow, Pang Teck Wai, Michael Leigh and Peter Boomgaard, who attended my seminars on various aspects of the book and made suggestions which helped clarify my ideas and arguments, a heartfelt thanks. I am also grateful to Gerda van Houtert who typed the original draft and Fay Hardingham who prepared the book for publication.

Finally, I acknowledge my indebtedness to my husband Ian Metcalfe who gave critical comments and drew the maps. My children, though too young to assist directly, gave me support and love while waiting anxiously for the book's completion. 


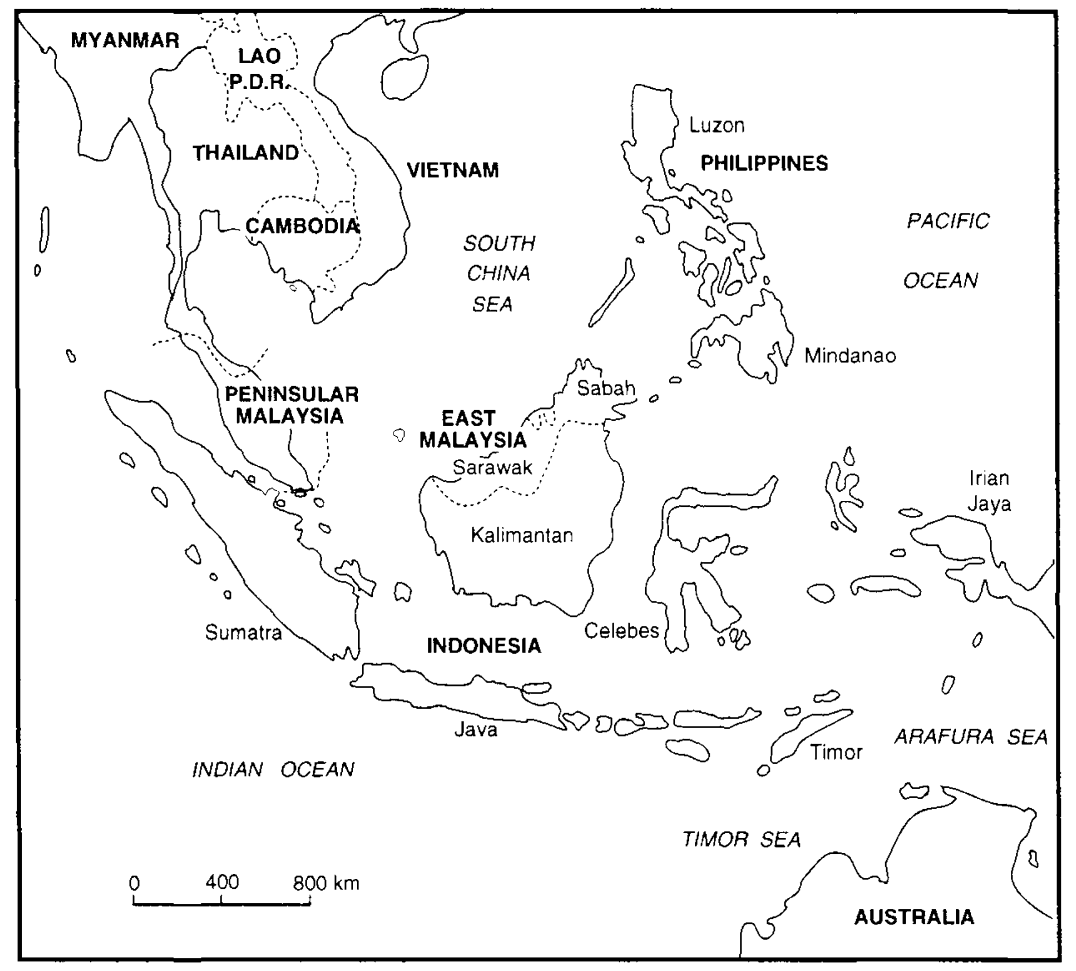

Map 1 Southeast Asia 


\section{Preliminary Note}

The term Sabah is used in the text to refer to the modern state of Sabah. Prior to 1963, the state was known as British North Borneo. Although the current practice is to refer to East Malaysia as Sabah and Sarawak, the term East Malaysia is used here in its geographical sense to refer to the two Borneo territories.

The new spelling system adopted by Indonesia and Malaysia has been followed for Malay words; for example pengiran. The spelling of place names and rivers follows current practice; for example, Kuching and Rajang.

All dollar figures quoted (unless otherwise stated) are in Straits (later Malayan/Malaysian) dollars or ringgit. In the nineteenth century the value of the Straits dollar fluctuated, but in 1904 it was pegged to sterling at the rate of $\mathrm{M} \$ 1.00$ to $2 \mathrm{~s} 4 \mathrm{~d}$ (about US $\$ 0.40-0.60$ in pre World War II terms). From 1947 to $1974 \mathrm{M} \$ 1.00$ was equal to about US\$0.33. Since 1973, when Malaysia opted out of the sterling area and floated the ringgit against the US dollar and the British pound, the ringgit has appreciated. 


\section{Maps and Figures}

Figure 3.1 Sarawak: Net Exports of Rubber, 1916-1941 49

Map 1 Southeast Asia xii

Map 2 States of Malaysia xix

Map 3 Sarawak and Brunei showing successive boundaries, 1841-1946 5

Map 4 Sabah: Chartered Company acquisitions, 1877-1901 7

Map 5 Sabah: Distribution of Rubber, 1940

Map 6 The Borneo Company in Sarawak 70

Map 7 Sarawak: Major Rivers and Shipping Routes 79

Map $8 \quad$ Sabah: Relief and Main Rivers 84

Map 9 Sabah: Rail and Shipping Links 88

$\begin{array}{lll}\text { Map } 10 & \text { Sarawak, Brunei and Sabah, } 1946 & 120\end{array}$

Map 11 Sarawak: Distribution of Mineral Resources 128

Map 12 Sabah: Distribution of Mineral Resources 132

Map 13 Sarawak: Road Network, 1963

Map 14 Sabah: Road Network, 1963 


\section{Tables}

Table 2.1 Population Growth in Sabah and Sarawak, 1911-47 19

Table 3.1 Sarawak: Mineral Production, 1868-1948 23

Table 3.2 Sadong Coal Mine Account, 1881-99 25

Table 3.3 Oil Production in Sarawak, 1911-24 27

Table 3.4 Sabah: Acreage under Main Crops, 1937-39 and 1950

Table 3.5 The Tobacco Industry and its Impact on Sabah's

Finances, 1881-96 40

Table 3.6 Expansion of the Rubber Industry in Sabah, 1902-40 43

Table 3.7 Sabah: Exports by Residency, 1909-26 45

Table 3.8 Sabah: Estimated Acreages of Principal Crops, 45

Table 3.9 A Comparison of the Exports of Sarawak in 1870 and $1940 \quad 51$

Table 3.10 Sarawak: Export Trade in Forest Products, 1873 and $1883 \quad 58$

Table 3.11 Sarawak: Quantity and Value of Gutta Exports, 18701940

Table 3.12 Sarawak: Exports of Other Forest Products, 18701940

Table 3.13 Sabah: Cumulative reported export value and relative importance of forest products, 1881-1915 61

Table 3.14 Sarawak: Exports by Value, 1900-29 72

Table 3.15 Sabah: Exports by Value, 1890-1929 72

Table 3.16 Sarawak and Sabah: Import and Export Values, 1870-1915

Table 3.17 Sarawak and Sabah: Export and Import Values, 1919-39

Table 4.1 Road Mileage in Sarawak, $1939 \quad 81$

Table 4.2 Road Mileage in Sabah, 1927-1940 92

Table 4.3 Prisoners Employed Annually by the Public Works Department, Kuching, 1890-1901 96

Table 4.4 Sarawak: Employment by Occupation and Ethnic Group, $1935 \quad 101$

Table 4.5 Number of Coolies Registered in Sabah, 1891-1940 109 
Table 4.6 Sabah and Sarawak: Revenue and Expenditure up to 1940

Table 5.1 Sabah: Analysis of Revenue Headings, 1938 and 1951

Table 5.2 Sarawak: Analysis of Revenue Headings, 1938 and 1951

Table 5.3 Sarawak and Sabah: Development Plans, 1947-63 126

Table 5.4 Value of Mineral Production in Sarawak, 1952-61 130

Table 5.5 Sabah: Acreage of Major Crops, 1940-63 138

Table 5.6 Sarawak: Exports and Value of Principal Products, 1940-62

Table 5.7 Sarawak: Timber Exports, 1920-60 146

Table 5.8 Sabah: Timber Exports, 1938-53 147

Table 5.9 Sabah: Timber Exports, 1955-63 148

Table 5.10 Sabah: Motor Vehicle Statistics, 1933-63 157

Table 5.11 Sabah: Economically Active Population by Gender, Community and Industry, 1960

Table 5.12 Sarawak: Economically Active Population by Gender, Community and Industry, 1960

$\begin{array}{lll}\text { Table 5.12 Continued } & 164\end{array}$

Table 6.1 Sabah and Sarawak: Population by Ethnic Group, 1960-91

Table 6.1 Continued

Table 7.1 Sabah: Exports of Oil and Copper, 1975-87

Table 7.2 Sabah, Sarawak and Peninsular Malaysia: Agricultural Production and Estate Yields, 1990

Table 7.3 Sabah: Export Values for Logs, Sawn Timber and Plywood, 1971-84

Table 7.4 Sabah: Utilisation of the tropical forest estate: deforestation due to shifting cultivation; area utilised for logging, end 1985

Table 7.5 Sarawak: Forest utilisation and deforestation

Table 7.6 Sarawak: Export values for logs and processed products, 1971-84

Table 7.7 Sabah, Sarawak and Peninsular Malaysia: Road Mileage and Density, 1990 
Table 7.8 Sabah, Sarawak and Peninsular Malaysia: Gross

Domestic Product by Industrial Origin, 1970, 1980 and 1990

Table 7.9 Distribution of Gross value of petroleum by percentage

Table 7.10 Sabah and Sarawak: State Government Revenue from Forestry and Petroleum, 1963-90

Table 7.11 Sabah, Sarawak and Peninsular Malaysia: Incidence of Poverty by Stratum, 1976, 1984, 1987 and 1990 


\section{Introduction}

Malaysia is currently approaching Newly-Industrialised Country (NIC) status. In 1990, nearly 27 per cent of GDP was from manufacturing industry. It is evident though that the extent of industrialisation is very different between Peninsular Malaysia and Sabah and Sarawak with the process much more advanced in Peninsular Malaysia. Geographically, culturally, and ethnically, Sabah and Sarawak are far away from the mainland and reap little visible benefit from the peninsula's economic success. The key to understanding uneven development in the Malaysian federation lies in its historical and recent past and to do justice to the complexities and history of Malaysia would far exceed the purpose and format of this book. However, it is necessary to relate at least a few of the facts which may convey some of the complexities and current issues of Malaysia today.

The modern state of Malaysia was formed in 1963 by the union of the Federation of Malaya, which had achieved independence from Britain in August 1957, the island of Singapore, which had been given internal selfgovernment by Britain in 1958, and the territories of Sabah and Sarawak, which had been British crown colonies from July 1946. On 9 August 1965, Singapore was expelled from the new Federation and became a separate independent state. Hence since August 1965, Malaysia has comprised the eleven states of what was then known as West Malaysia and the two Borneo states of East Malaysia (See Map 2). In the early 1970s the term West Malaysia was officially changed to Peninsular Malaysia while East Malaysia was changed to Sabah and Sarawak, allegedly after the secession of Bangladesh from Pakistan.

\section{Geographic Location}

Peninsular Malaysia forms part of the southern projection from the Asian mainland, with Thailand immediately to its north and the island of Singapore to the south. It has an area of 131794 square kilometres and consists of eleven states: Perlis, Kedah, Penang, Perak, Selangor (with the Federal Capital Territory of Kuala Lumpur), Melaka, Johor, Negeri Sembilan, Pahang, Trengganu and Kelantan.

Sabah and Sarawak occupy the northern and northwestern coast of the island of Borneo. Sabah lies approximately between latitude $4^{\circ}$ and $7^{\circ}$ North and longitude $115^{\circ}$ and $119^{\circ}$ East. Sarawak lies between latitude $0^{\circ} 50^{\prime}$ and $5^{\circ}$ North and longitude $109^{\circ} 36^{\prime}$ and $115^{\circ} 40^{\prime}$ East. Together they occupy an area of 198,149 sq km (Sabah - 73 700; Sarawak - 124 449) in comparison to their neighbours, Brunei Darussalam (5765) and Kalimantan, Indonesia (539 460). 


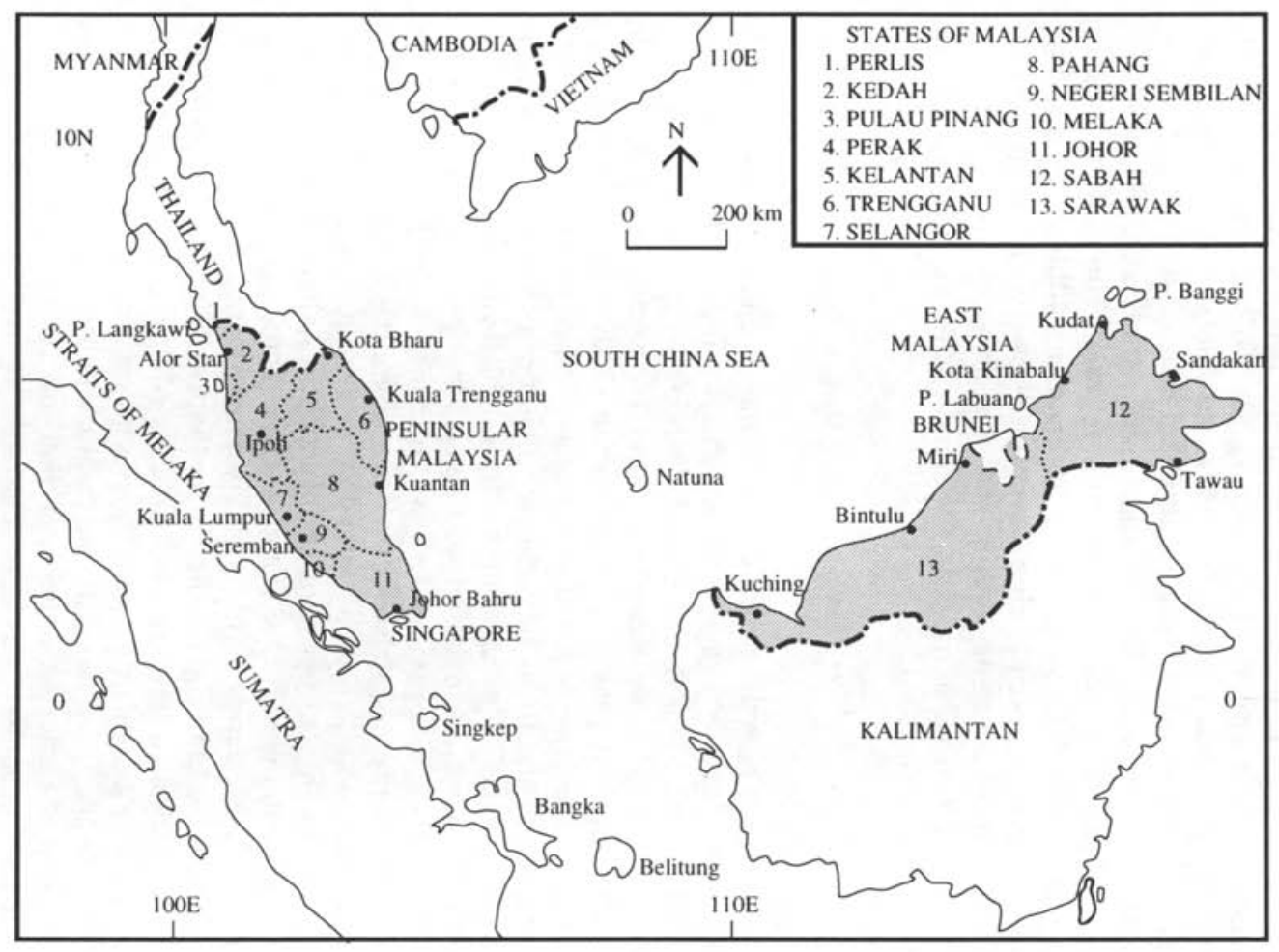

$\vdots$
$\vdots$
$\vdots$
$\vdots$
$\vdots$

Map 2 States of Malaysia 


\section{Climate and Rainfall}

Both Peninsular and East Malaysia have a uniformly warm and humid climate with temperatures ranging from $25.5^{\circ} \mathrm{C}$ to $33^{\circ} \mathrm{C}$, except at high altitudes where the nights are considerably cooler. Seasonal changes are marked not by variations in temperature but by changes in rainfall, which in turn are related to the cycle of the monsoonal winds. The northeast monsoon, which sweeps down across theSouth China Sea, is the dominating air stream during November to January. It then gradually decreases in force with a transitional period in April to May followed by the southwest monsoon. Another transitional period occurs in October to November and the whole cycle then repeats. Throughout most of Malaysia the rainfall ranges from $2000 \mathrm{~mm}$ to $4000 \mathrm{~mm}$ per annum, although there is considerable variation between different regions. Nowhere is there a true dry season, but most areas receive more rainfall during certain periods in the year, the wettest season coinciding with the northeast monsoon.

\section{The Physical Environment}

The landform of both the peninsula and Borneo is characterised by coastal plains giving way to a rugged mountainous interior. The spine of the peninsula is the Main Range, and there is a further block of highland covering most of upper Kelantan, inland Trengganu and Pahang. The peninsula's highest peak is Gunung Tahan (2207 metres). The interior mountains have always posed a formidable barrier to trans-peninsular movement and the focus of settlement has been the coastal lowlands. From early times, political centres were established on the rivers which have their headwaters in the inland ranges. Most peninsular states derive their name from the principal rivers. In Borneo, the lowlands, often swampy alluvial plains, also form a belt along the coast. Behind these plains are the foothills leading inland up to a mountainous mass through which runs the border between Malaysian and Indonesian Borneo. The highest mountain in Borneo, and also in Southeast Asia, is Mount Kinabalu ( 4500 metres). The great rivers of Borneo, like those on the peninsula, were the original sites of settlement. The heavy rainfall and warm temperatures have resulted in East Malaysia being covered by equatorial forests. Indeed, Borneo possesses one of the richest and most diverse flora and fauna on earth, and the trade in tropical timber represents a major export earner for Sabah and Sarawak. Along the plains most of the original forest cover has been removed to make way for settlements, physical infrastructure, commercial agriculture and industries. 


\section{Population}

Ethnic considerations and religious affiliations are another sphere of Malaysian diversity. In 1991, Malaysia's population was an estimated 18.4 million of which about 14.8 million live on the peninsula, while Sabah's population totalled 1.8 million and Sarawak's 1.7 million. In Peninsular Malaysia, the dominant ethnic group is the Malays. In Sabah, the dominant group is of Kadazan origin, while in Sarawak the Dayaks predominate. The categorisation of the local peoples in East Malaysia has been a difficult task and the resulting classification conceals considerable variation in language and life style. Both Peninsular and East Malaysia were land-abundant, labour-scarce economies and consequently immigration has been an important factor underlying population growth in the nineteenth and early twentieth centuries. In East Malaysia, immigration from China and the Netherlands East Indies was a major driving force in pushing total population growth rates.

\section{Political Patterns}

The British colonial authorities fostered the incorporation of the independent Borneo territories with Malaya and Singapore to form the Malaysian Federation. Initially, there was considerable apprehension in Sabah and Sarawak resulting in the formation of a number of political parties structured along communal lines. Nevertheless, early opposition to the Federation by East Malaysian leaders soon faded, largely because Malaya was prepared to make a number of important concessions and also because Sabah and Sarawak were concerned over the aggressive stance adopted towards them by Indonesia and the Philippines. Over the years there has been an underlying tension in this relations between the federal government in Kuala Lumpur and the state governments of Sabah and Sarawak. In essence this tension has derived from the notably lower level of economic development and political sophistication in Sabah and Sarawak. On the whole, smooth federal-state relations have been guaranteed because the federal government has continued to ensure the supremacy of those political leaders who co-operate fully with it.

What does all this mean for Sabah and Sarawak? The leaders of these two states are preoccupied with trying to catch up to the social and economic progress of West Malaysia. Their economic goals as a whole have fostered general attitudes to the environment which are seen as inimical to conservation by conservationists. Thus current strategies for parcelling out land for settlement for expansion of commercial agriculture and for logging have largely been carried out in the name of development and these leaders have shown a greater tendency to discourage environmental criticism of their policies than to incorporate conservation into their development agenda. 
This book's main theme is a long-term view of East Malaysia's economic growth. While its focus is on economic development during the first four decades, it also links the post-World War II period (1946-63) with the national period (1963 onwards). In other words, the contexts in which economic change will be analysed will be both historical and comparative. The virtue of this approach is twofold. Firstly, an historical orientation will supply a necessary corrective to the impression that export-oriented development (especially in Sarawak) is a recent phenomenon and represents a sharp departure from the past. Secondly, a comparative investigation can highlight patterns of development and experience that is not easily discernible in single country studies.

A second theme relates to the role of the state. Was the role of the Chartered Company and the Brooke Administration in relation to economic growth only a limited one in comparison to the British role in the Malay peninsula? Furthermore, one might think there would be a striking contrast between a state governed benevolently by the Brookes on the one hand, and by a chartered company seeking profits on the other. My study shows that despite being different 'states', the result in terms of policies was actually very similar.

Another theme is the integration of the two economies not only into the international economy but into Malaysia. Despite initially lacking comparable locational and infrastructional facilities to attract major investment, the two Borneo states had, from at least the First World War, become complementary in terms of their raw materials rather than competitive with Singapore/Malaya. After the Second World War, the colonial government completed the process so that at the time of Independence the economies of the two states were much closer to that of West Malaysia.

The book is structured in three parts. The first and main section focuses on economic development in Sabah and Sarawak during the period $1850-1940 . *$ It is argued that the foundations of an export-oriented economy were laid during this period. The second part analyses economic change during the colonial period (1946-1963). It is argued here that colonial development policies were designed to promote territorial unity in North Borneo and to integrate Sabah and Sarawak in the MalayanSingaporean economy and the wider Southeast Asian trading network. The third part deals with the post-independence period when federal policies were seen as a central force making for integration of economic activity in the Malaysian federation.

* It is not proposed here to deal specifically with the brief Japanese Occupation period (1942-45) since there was no significant departure from previous economic trends. 